\title{
A Strain of Clover yellow vein virus that Causes Severe Pod Necrosis Disease in Snap Bean
}

\author{
Richard C. Larsen and Phillip N. Miklas, Unites States Department of Agriculture-Agricultural Research Service, \\ Prosser, WA 99350; Kenneth C. Eastwell, Department of Plant Pathology, Washington State University, IAREC, \\ Prosser 99350; and Craig R. Grau, Department of Plant Pathology, University of Wisconsin, Madison 53706
}

\begin{abstract}
Larsen, R. C., Miklas, P. N., Eastwell, K. C., and Grau, C. R. 2008. A strain of Clover yellow vein virus that causes severe pod necrosis disease in snap bean. Plant Dis. 92:1026-1032.

Soybean aphid (Aphis glycines) outbreaks occurring since 2000 have been associated with severe virus epidemics in snap bean (Phaseolus vulgaris) production in the Great Lakes region. Our objective was to identify specific viruses associated with the disease complex observed in the region and to survey bean germplasm for sources of resistance to the causal agents. The principle causal agent of the disease complex associated with extensive pod necrosis was identified as Clover yellow vein virus (ClYVV), designated ClYVV-WI. The virus alone caused severe mosaic, apical necrosis, and stunting. Putative coat protein amino acid sequence from clones of amplicons generated by reverse-transcription polymerase chain reaction was $98 \%$ identical to ClYVV strain no. 30 identified in Japan that has not been reported to cause pod necrosis. ClYVV-WI amplicons were 96\% identical to a mild strain of ClYVV from Oregon. A distinguishing feature of this new strain is that it does not react with Potyvirus broad-spectrum monoclonal antibody PTY 1. A survey of common bean lines and cultivars revealed that, in addition to UI-31 and US1140 with known resistance to CIYVV, lines with the $b c-3$ gene for resistance to Bean common mosaic necrosis virus also were resistant to ClYVV-WI. An evaluation of 63 snap bean cultivars and breeding lines revealed just one, Roma 442, with a moderate level of tolerance to ClYVV-WI. Introgression of the $b c-3$ gene and resistances from UI-31 and US1140 into snap bean may offer a high level of resistance to extensive pod necrosis disease caused by ClYVV in the Great Lakes region.
\end{abstract}

Snap bean (Phaseolus vulgaris L.) is a major crop in the Great Lakes region of the United States. The most significant production occurs in Wisconsin, Michigan, New York, Illinois, and Pennsylvania. Snap bean crops also are produced in the Pacific Northwest, Georgia, Florida, and Ontario, Canada. In 2005, 124,367 ha of snap bean were harvested with a farm gate value of approximately $\$ 400$ million (35). Because most snap bean pods are produced for fresh market, freezing, or canning, pods harvested with imperfections due to disease or mechanical injury are discarded, effectively reducing the growers' yield. Pods harvested with imperfections that exceed allowable thresholds result in rejection by processors of the entire harvest.

Snap bean cultivars in the United States are susceptible to many important plant

Corresponding author: Richard Larsen

E-mail: richard.larsen@ars.usda.gov

* The $\boldsymbol{e}$-Xtra logo stands for "electronic extra" and indicates that Figures 1 and 2 appear in color in the online edition.

Accepted for publication 14 February 2008.

doi:10.1094/PDIS-92-7-1026

This article is in the public domain and not copyrightable. It may be freely reprinted with customary crediting of the source. The American Phytopathological Society, 2008. viruses that may constrain production in the absence of resistance. The potential negative effect of viruses on snap bean production was fully evident in 2000 when a severe virus outbreak occurred in Wisconsin and other neighboring snap bean production states. The most frequently detected viruses included Cucumber mosaic virus $(\mathrm{CMV})$ and many distinct strains of Alfalfa mosaic virus (AMV) $(8,13)$. The high populations of the soybean aphid (Aphis glycines) in adjacent soybean fields (9). A high incidence of mixed infections of CMV and AMV was associated with necrotic lesions or line patterns on pods (8). Other viruses detected included Bean common mosaic virus (BCMV), Bean yellow mosaic virus (BYMV), Clover yellow mosaic virus, Tobacco streak virus, and White clover mosaic virus. Although BCMV was detected, Bean common mosaic necrosis virus (BCMNV) never was detected in any samples evaluated.

Significant virus outbreaks again occurred in 2001 (13) and 2003 to 2005 (R. Larsen, unpublished) in Iowa, Illinois, Kentucky, Michigan, Minnesota, New York, Wisconsin, and the province of Ontario, Canada. The same complex of viruses resulted in yield losses up to $100 \%$, especially in fields of late-season processing and fresh-market snap bean crops. During these growing seasons, snap bean outbreaks were directly associated with plants in fields were observed showing extensive external and internal pod necrosis, a disease termed "chocolate pod" by local growers. The necrosis frequently affected 75 to $100 \%$ of the pod surface. Clover yellow vein virus (ClYVV) (family Potyviridae, genus Potyvirus) was suspected as the causal agent based on preliminary host range response; however, identity of the pathogen was not immediately confirmed. CIYVV causes mild to severe mosaic, leaf malformation and vein necrosis, stunting of the plant, and apical necrosis in highly susceptible cultivars (22). Pods often are mottled, twisted, or malformed. Symptoms in bean plants infected with CIYVV can be highly variable due to the numerous strains of the virus and their interaction with different bean cultivars. Symptoms frequently resemble those caused by the closely related Potyvirus BYMV, making visual distinction between the two viruses difficult.

Genes for resistance to ClYVV have been reported in the literature. The $c y v$ gene present in US1140 (23) was transferred to 'Black Knight' (27), UI-31 possesses two recessive genes (32), and the desc gene discovered in snap bean cv. Jolanda also was present in snap bean cultivars Imuna and Evolutie (26). The latter three cultivars are not currently grown in the United States. The reactions of these resistant sources against isolates of ClYVV from the Great Lakes region are unknown. To our knowledge, no other commercial snap bean cultivars have been evaluated for resistance or tolerance to ClYVV. The objectives of this work were to validate whether ClYVV was responsible for the chocolate pod disease in snap bean, and to identify sources of resistance to the virus.

\section{MATERIALS AND METHODS}

Field isolates, host plants, and serology. Snap bean plants exhibiting leaf mosaic, apical stem necrosis, and pod necrosis symptoms were collected from fields in Wisconsin, Michigan, Minnesota, Ohio, and New York during the 2001-05 growing seasons. Samples were tested routinely by indirect enzyme-linked immunosorbent assays (ELISA) (2) for AMV using a polyclonal antiserum produced at the United States Department of AgricultureAgricultural Research Service (USDAARS) laboratory in Prosser, WA, and for 
CMV using commercially available polyclonal antiserum (Agdia, Inc., Elkhart, IN). The group-specific ELISA for potyviruses used monoclonal antibody (MAb) PTY 1 developed by Jordan (10) and commercially available (Agdia, Inc.). Assays were performed according to the manufacturer's protocols. Reactions were evaluated 30 min and $24 \mathrm{~h}$ after the addition of substrate. Leaf tissue exhibiting mosaic symptoms was ground using a mortar and pestle in $50 \mathrm{mM}$ potassium phosphate buffer, $\mathrm{pH}$ 7.4 , containing $10 \mathrm{mM}$ sodium sulfite. The extract then was used to inoculate a limited selection of diagnostic bean host plants, including 'Hystyle,' 'Sutter Pink,' 'Black Turtle II,' and UI-34. Chenopodium quinoa Willd. and $C$. amaranticolor Coste \& Reynier were used as local lesion hosts. When other viruses were suspected based on visual diagnosis or detection by ELISA, local lesions were carefully excised from C. quinoa as soon as they became visible, ground as above, and inoculated to $C$. quinoa, Sutter Pink, and Hystyle.

Cultures of ClYVV determined to be free of other viruses were inoculated onto UI-34, Hystyle, 92US-1006, and snap bean breeding line PS00-221A from the USDAARS, Prosser, WA, bean-breeding program; all were determined to be susceptible to ClYVV. Inoculated plants were maintained in the greenhouse and observed for symptoms of necrosis on developing pods.

Primer design. To differentiate ClYVV from BYMV by reverse-transcription polymerase chain reaction (RT-PCR), DNA primers were designed using available sequences in the National Center for Bio- technology Information GenBank database for each virus. Target areas for forward and reverse primers were selected from conserved regions in nucleotide sequence alignments of nine different accessions (AB003308, AB011819, AF185959, AF203536, AY169801, D86044, D89539, D89540, and S77521) of ClYVV and eight accessions (AB029436, AB029436, AY178050, AY192568, D28819, D83749, DQ641248, and U47033) of BYMV. The forward (F) primers for ClYVV and BYMV were located in the NIb region of the viral polyprotein. The reverse (R) primer for ClYVV was located at the $3^{\prime}$ terminus of the coat protein $(\mathrm{CP})$ gene, and the reverse primer for BYMV was located at the $3^{\prime}$ terminus of the nontranslated region. The primer sequences are as follows: ClYVV-F, 5'-TTGATGACAGCC AGATG-3'; ClYVV-R, 5'-GAATCGTGC TCCAGCAATG-3'; BYMV-F, 5'-GAT GGAGAGGAGCAGGTGCAC-3'; and BYMV-R, 5'-CTCGCTCTACAAAGA TCAG-3'.

Total nucleic acid preparation and RT-PCR. From bean plants determined not to be infected with CMV or AMV based on ELISA results but suspected to be infected with ClYVV or BYMV, total nucleic acid was extracted using the method described by Dellaporta (4) as modified by Presting et al. (20), except that $100 \mathrm{mg}$ of tissue was macerated in buffer without the use of liquid nitrogen. After washing with $70 \%$ ethanol, the final pellet was resuspended in $300 \mu \mathrm{l}$ of sterile water. Reverse transcription was performed in reactions containing $50 \mathrm{mM}$ Tris, $\mathrm{pH} 8.0 ; 75 \mathrm{mM}$ potassium chloride; $3 \mathrm{mM}$ magnesium chloride; $5 \mathrm{mM}$ dithiothreitol; $500 \mathrm{mM}$ each dATP, dCTP, dGTP, and dTTP; and 1 $\mu \mathrm{M}$ reverse primer. After the addition of 5 $\mu \mathrm{l}$ of total nucleic acid, the final reaction was brought to $20 \mu \mathrm{l}$ with sterile water. After $3 \mathrm{~min}$ at $70^{\circ} \mathrm{C}$ followed by cooling to $4^{\circ} \mathrm{C}, 200$ units of Moloney murine leukemia virus reverse transcriptase (Promega Corps., Madison, WI) was added to the reaction and incubated at $42^{\circ} \mathrm{C}$ for $1 \mathrm{~h}$. The subsequent PCR amplification consisted of $25-\mu \mathrm{l}$ reactions containing $2 \mu \mathrm{l}$ of firststrand cDNA template; $10 \mathrm{mM}$ Tris, $\mathrm{pH}$ $8.0 ; 50 \mathrm{mM}$ potassium chloride; $0.1 \%$ Triton X-100; $1.5 \mathrm{mM} \mathrm{MgCl}_{2} ; 150 \mathrm{mM}$ each dATP, dCTP, dGTP, and dTTP; 500 $\mathrm{nM}$ each forward and reverse primer; and 1 unit of Taq DNA polymerase (Promega Corp.). Thermocycling parameters were optimized and a final profile was employed that consisted of a single cycle of $2 \mathrm{~min}$ at $95^{\circ} \mathrm{C}$; followed by 35 cycles of $1 \mathrm{~min}$ at $94^{\circ} \mathrm{C}, 1 \mathrm{~min}$ at $58^{\circ} \mathrm{C}$, and $1 \mathrm{~min}$ at $72^{\circ} \mathrm{C}$; followed by a final extension step for 7 $\min$ at $72^{\circ} \mathrm{C}$. Reaction products were resolved by electrophoresis through $1.5 \%$ agarose gels containing $1 \times$ Tris-acetateEDTA buffer (24). DNA was purified from the gel bands using GeneCapsule (Geno Technology, Inc. St. Louis) and cloned into the vector pCR4 using the TOPO TA cloning kit (Invitrogen, Carlsbad, CA) according to the manufacturer's instructions. Plasmid DNA was purified from Escherichia coli DH $10 \beta$ using alkaline lysis (24) and clones containing the RT-PCR product were sequenced using the dideoxy-chain termination method.

Evaluation of common bean for resistance to CIYVV. Once involvement of

Table 1. Reaction of genotypes within Bean common mosaic virus (BCMV) and Bean common mosaic necrosis virus (BCMNV) host groups to Clover yellow vein virus $(\mathrm{ClYVV})^{\mathrm{a}}$

\begin{tabular}{|c|c|c|c|c|c|}
\hline \multirow[b]{3}{*}{ Host group } & \multirow[b]{3}{*}{ Host differential } & \multirow[b]{3}{*}{ Resistance genes } & \multicolumn{3}{|c|}{ Symptoms $^{b}$} \\
\hline & & & \multirow{2}{*}{$\begin{array}{c}\text { Primary } \\
11 \mathrm{dpi}\end{array}$} & \multicolumn{2}{|c|}{ Secondary } \\
\hline & & & & 21 dpi & 50 dpi \\
\hline 0 & Sutter Pink & None & VN & TN, D & $\mathrm{D}$ \\
\hline 1 & Stringless Green Refugee & $i, b c-u$ & VN & $\mathrm{D}$ & $\mathrm{D}$ \\
\hline 2 & Redlands Greenleaf C & $i, b c-u, b c-1$ & CLL & sst, sM, D & $\mathrm{D}$ \\
\hline 2 & Imuna $^{c}$ & $i, b c-u, b c-1$ & NS & sst, sM & sst, sM \\
\hline 3 & Redlands Greenleaf B & $i, b c-u, b c-1^{2}$ & CLL & sst, sM, D & $\mathrm{D}$ \\
\hline 3 & UI-59 & $i, b c-u, b c-1^{2}$ & NS & NS & $\mathrm{M}$ \\
\hline 3 & US1140 & $i, b c-u, b c-1^{2}$ & NS & NS & NS \\
\hline 4 & Sanilac & $i, b c-u, b c-2$ & VN & $\mathrm{D}$ & $\mathrm{D}$ \\
\hline 5 & UI-114-8 Pinto & $i, b c-u, b c-1, b c-2$ & NS & NS & $\mathrm{M}$ \\
\hline 6 & UI-31 ${ }^{\mathrm{c}}$ & $i, b c-u, b c-1^{2}, b c-2^{2}$ & NS & NS & NS \\
\hline 6 & Othello & $i, b c-u, b c-2^{2}$ & VN & $\mathrm{TN}$ & $\mathrm{D}$ \\
\hline 7 & IVT 7214 & $i, b c-u, b c-2, b c-3$ & NLL & sM, st & sM, st, TN \\
\hline 8 & Black Turtle I & $I$ & NLL, VN & $\mathrm{D}$ & $\mathrm{D}$ \\
\hline 9 & Jubila & $I, b c-1$ & NLL & M, D & $\mathrm{D}$ \\
\hline 9 & Jolanda $^{\mathrm{c}}$ & $I, b c-1$ & NS & sst, sM & sst, sM \\
\hline 10 & Red Kloud & $I, b c-l^{2}$ & CLL & sst, sM, Bl & sst, sM, B1 \\
\hline 11 & 92US-1006 & $I, b c-u, b c-2^{2}$ & NS & NS & $\mathrm{TN}$, pod lesions \\
\hline 12 & TARS-VR-1s & $I, b c-3$ & NS & NS & NS \\
\hline
\end{tabular}

${ }^{a}$ All lines were evaluated using ClYVV-WI and ClYVV-OR (strains from Wisconsin and Oregon, respectively) in separate experiments. Host plants reacted similarly with each strain, except symptoms caused by CIYVV-WI were more severe. Only symptoms caused by ClYVV-WI are listed in the table.

${ }^{\mathrm{b}}$ Symptom legend: $\mathrm{Bl}=$ blistering, $\mathrm{CLL}=$ chlorotic local lesions, $\mathrm{M}=$ mosaic, $\mathrm{mM}=$ mild mosaic, $\mathrm{NLL}=$ necrotic local lesions, $\mathrm{NS}=$ no symptoms, $\mathrm{D}=$ plant death, $\mathrm{sM}=$ severe mosaic, $\mathrm{st}=$ stunted growth, $\mathrm{sst}=$ severe stunting, $\mathrm{TN}=$ top $($ systemic) necrosis, and $\mathrm{VN}=$ vein necrosis; dpi $=$ days post inoculation.

${ }^{\mathrm{c}}$ Lines and cultivars with resistance to ClYVV reported in the literature. 
ClYVV in the disease complex was determined and verified, biological assays were initiated to identify potential genes for resistance to ClYVV isolated from infected snap bean from Wisconsin, hereon referred to as ClYVV-WI. Because US1140, UI-31, 'Jolanda,' and 'Imuna' have been reported as resistant to CIYVV (23,25-27), we evaluated their resistance to the newly obtained strain of ClYVV from Wisconsin. Seedlings of each line in several repeated experiments were inoculated at the primary leaf stage and maintained in the greenhouse for at least 50 days.

The limited diagnostic host range described above was expanded to include a set of bean differentials representative of each of 12 host groups developed by Drijfhout et al. (6) for identification of strains of BCMV and BCMNV. The differentials represent eight resistance genes or combinations thereof and are listed in Table 1. Inoculated plants were maintained in a greenhouse at 18 and $30^{\circ} \mathrm{C}$ (night and day, respectively) under natural light for symptom development. A collection of 63 commercial snap bean cultivars and breeding lines also was screened for resistance to ClYVV-WI with the intent of identifying a resistance source of immediate use to the snap bean industry. To compare the biological effects of ClYVV-WI with other known strains of ClYVV, the lines were screened additionally with a mild strain of ClYVV from Oregon (ClYVV-OR) iso-

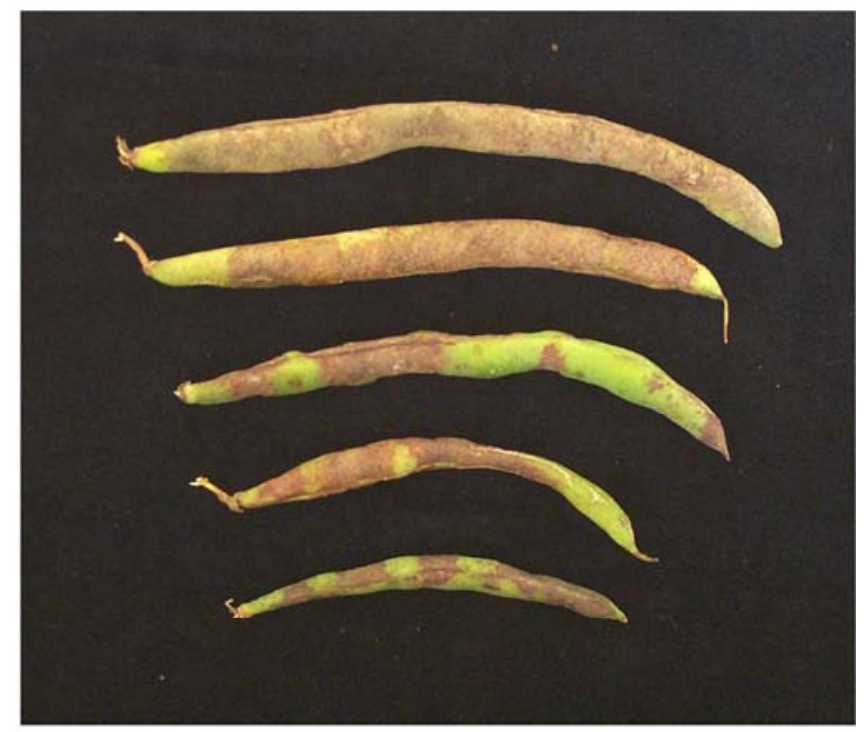

A

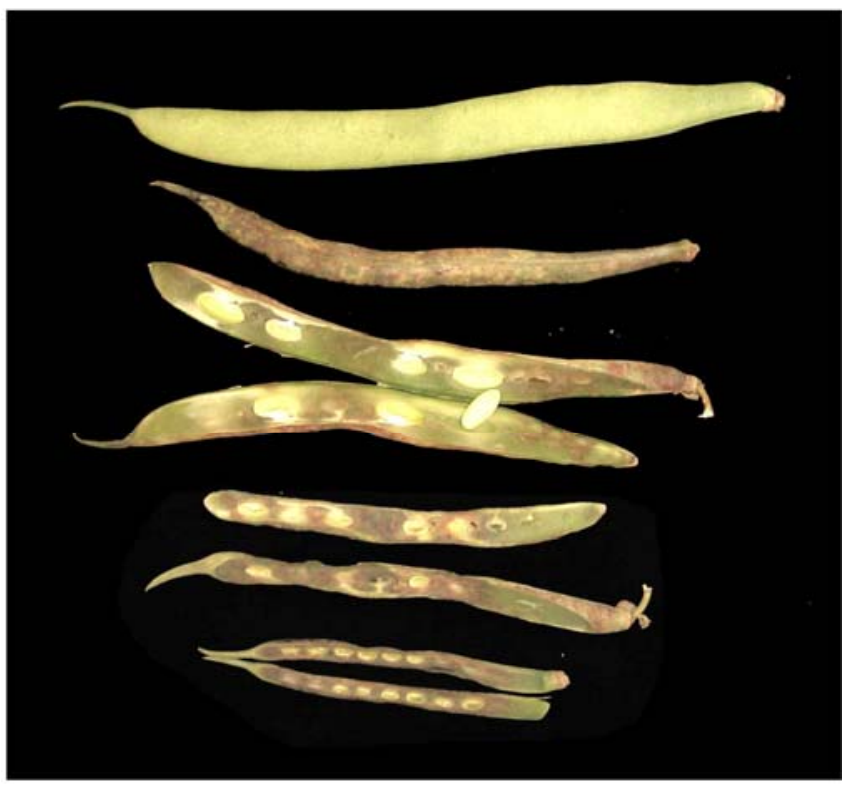

B

Fig. 1. A, Extensive external pod necrosis symptoms on snap bean caused by infection with the Clover yellow vein virus isolate from Wisconsin. B, Snap bean pods cut longitudinally showing internal and external necrotic areas resulting from infection with the Clover yellow vein virus isolate from Wisconsin. Uppermost pod is healthy.

lated from pea (Pisum sativum L.) and a strain from New York (ClYVV-NY) described by Provvidentti et al. (23).

Three individual plants of each line or cultivar were mechanically inoculated at the primary leaf stage with each of the strains. The procedure was repeated 2 days following the first inoculation to reduce the possibility of escapes. Plants were maintained under greenhouse conditions and evaluated based on symptom response. A disease severity index (dsi) was assigned as follows: 1 = no disease symptoms; 2 = mild mosaic on secondary leaves and no observable stunting; 3 = mosaic, leaf roll, stunting; 4 = severe mosaic, severe stunting, leaf roll, blistering; and $5=$ severe mosaic, systemic vein necrosis, apical necrosis, plant death.

\section{RESULTS}

Field observations and host response. Snap bean samples obtained from the Great Lakes region between 2000 and 2005 with pods showing varying levels of necrosis were evaluated for the presence of viruses, with focus on ClYVV. All pods determined by RT-PCR to be infected with ClYVV from Wisconsin (and other neighboring states) exhibited extensive brown to rust-colored pod necrosis that often affected the entire pod (Fig. 1A). Pods frequently showed internal necrotic areas (Fig. 1B). By comparison, CMV and AMV were detected as a coinfection in pods exhibiting necrosis that was less severe, more localized, and somewhat darker in color (Fig. 2). Reactions on bean plants in grower's fields infected with either ClYVV or BYMV consisted of foliar symptoms typical of these viruses, including severe stunting and mosaic. Apical (top) necrosis occurred with infection by ClYVV in field-grown Hystyle and on greenhouse-grown Sutter Pink, Black Turtle II, UI-34, and Hystyle inoculated with ClYVV-WI. Top necrosis on these hosts never was observed in the field or greenhouse when infected with BYMV only; however, severe mosaic symptoms were typical on leaves and mottling was often observed on the pods.

ClYVV-WI caused local lesions on $C$. quinoa and $C$. amaranticolor. Virus symptoms became systemic on both hosts, causing severe vein and leaf necrosis, malformation, and stunting. Symptoms caused by BYMV in C. amaranticolor included local chlorotic lesions followed by systemic vein yellowing and slightly malformed leaves.

Serology and RT-PCR. Bean samples exhibiting the characteristic pod necrosis disease or foliar symptoms, and infected with CIYVV but not BYMV, did not react positively with the Potyvirus groupspecific PTY 1 MAb. In contrast, samples exhibiting symptoms typical of BYMV such as leaf mosaic or yellow mosaic reacted positively with the PTY 1 Potyvirus MAb. For the purpose of determining the 
effect of ClYVV-WI alone, samples testing positive for BYMV, CMV, or AMV were eliminated from further testing.

In all cases where extracts from symptomatic leaves of plants exhibited pod necrosis but tested negative by ELISA with the Potyvirus MAb PTY 1, the plant extract subsequently yielded a positive reaction by RT-PCR using DNA primers designed for the detection of ClYVV. No amplicons were produced with the BYMV primers from any samples with pod necrosis that did not react with MAb PTY 1 . In contrast, preparations from samples that exhibited symptoms typical of BYMV tested positive with the Potyvirus MAb and produced amplified products $(1,113 \mathrm{bp})$ by RT-PCR using the BYMV-specific primers (data not shown). Neither CIYVV nor BYMV amplicons were produced from leaf samples of bean plants that did not exhibit visible foliar symptoms. Extracts from symptomless plants did not yield any detectable infection of host range plants after mechanical inoculation.

In some cases, CIYVV amplicons were produced from chocolate pod tissue originating from field samples where foliar symptoms were absent. When test plants were inoculated with leaf and pod tissue from these samples, infection was established only from pod tissue. Infection with the virus subsequently was verified by RTPCR. Interestingly, no symptoms were produced in test plants inoculated with expressed sap from the symptomless leaves, and no amplicons were produced from total nucleic acid extracted from these samples.

Nucleotide sequence of amplicons (835 bp) was determined for two clones each of the CIYVV-WI RT-PCR products obtained from four different snap bean samples after local lesion transfer. Nucleic acid sequence identity was greater than $98 \%$ within each pair of clones. The sequence encoding the $\mathrm{CP}$ of ClYVV-WI was deposited in GenBank (accession no. EF591473). Nucleic acid sequence identities ranged from 83 to 96\% with other ClYVV CP sequences available in GenBank whereas amino acid identities ranged from 91 to $98 \%$. The most common amino acid change between samples was substitution of the proline residue with serine at position 19 in the motif SKDKEP, and the glycine residue with glutamic acid at position 94 in the motif TQEQLE (Fig. 3).

Compared with ClYVV-OR, 5 amino acid substitutions occurred within the first 50 residues of ClYVV-WI at positions 6, 19, 26, 34, and 47 (Fig. 3). ClYVV-WI contained the NAG aphid transmission motif located seven residues downstream of the CP $5^{\prime}$ N-terminus, which is consistent with all other known isolates of ClYVV. The amino acid sequence alignment of ClYVV-WI was $96 \%$ identical with the CP gene sequence of ClYVV-OR (Fig. 3). When compared with Japanese strain ClYVV no. 30 (accession no. NP734172), a strain not reported to cause pod necrosis $(26,34)$, only four amino acid substitutions occurred in the CP sequence, corresponding to $98 \%$ identity level (Fig. 3).

Evaluation of common bean lines for resistance to CIYVV. Susceptible dry bean lines expressed typical symptoms resulting from infection with ClYVV. All BCMV host differentials screened were susceptible to ClYVV-WI and CIYVV-OR except UI-31 and US1140, and TARS-VR1 s with $I+b c-3$ genes (Table 1). Lines 92US-1006 and UI-114-8 Pinto initially appeared to be resistant but subsequently showed characteristic virus symptoms by 50 days post inoculation (dpi). Reactions of the host differentials to inoculations with ClYVV-WI and ClYVV-OR were consistent across resistant and susceptible lines, except that symptoms in susceptible lines were considerably more severe with ClYVV-WI than with ClYVV-OR. ClYVV was not detected by RT-PCR in bean lines that did not develop symptoms; thus, these were considered resistant. Additional dry bean lines with $I+b c-3$ (USLK-1, USLK2, USLK-3, USDK-4 USDK-5, USWK-6, USCR-7, USCR-9, and Raven; 15-19), and with $b c-3$ alone (USCR-8; (17) remained symptomless after $50 \mathrm{dpi}$ and tested negative for CIYVV by RT-PCR .

Evaluation of commercial snap bean cultivars. Sixty-three snap bean cultivars and breeding lines inoculated with three different strains of ClYVV (-OR, -NY, and -WI) exhibited typical symptoms of infection by ClYVV except 'Roma 442,' a Romano type bean that remained symptomless for up to $21 \mathrm{dpi}$ (Table 2). At 50 dpi, this cultivar had developed leaf mosaic but did not exhibit stunting symptoms, apical necrosis, or pod necrosis. Infection in Roma 442 was verified by RT-PCR and by back-inoculation to indicator hosts. In additional experiments, Roma 442 was inoculated with the NL3-D strain of BCMNV. Inoculated plants showed epinasty and vein necrosis on inoculated primary leaves followed by severe stunting and top necrosis, a response indicating $I$ gene presence but not $b c-3$. All snap bean lines except Roma 442 were rated susceptible to highly susceptible to ClYVV. All plants with a dsi $=5$ rating at 7 dpi had responded with vein necrosis on inoculated primary leaves. This was followed by severe stunting, apical necrosis, and death, usually within 14 to 21 dpi. Similar to observation of symptoms in dry bean, ClYVV-OR produced milder symptoms on 46 of 63 snap bean lines relative to those symptoms produced by ClYVV-WI or ClYVV-NY (Table 2).

\section{DISCUSSION}

CIYVV isolated from snap bean in Wisconsin and other areas of the Upper Midwest and New York is a previously unreported strain that causes extensive pod

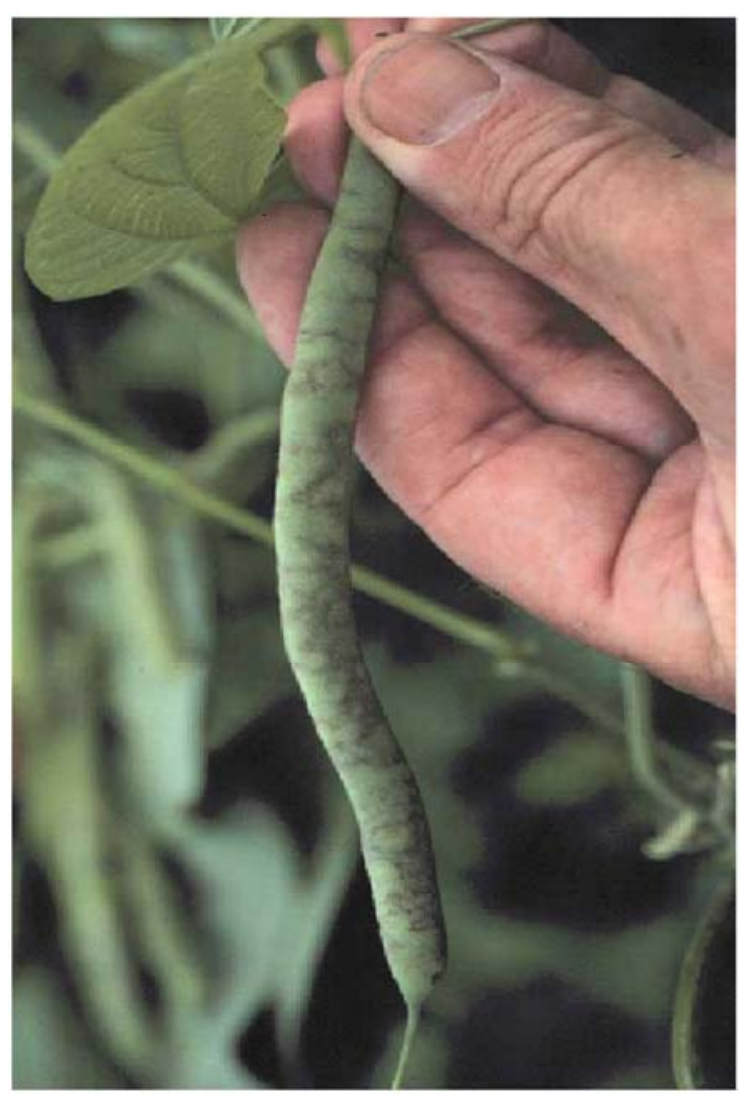

Fig. 2. Pod symptoms on a commercial snap bean cultivar co-infected with Cucumber mosaic virus and Alfalfa mosaic virus. 
necrosis. The necrosis was typically more severe than that caused by the complex of CMV and AMV, and is referred to as chocolate pod by local growers $(8,31)$. These pod symptoms have not been observed or reported on snap bean as a result of infection by previously identified strains of ClYVV. Generally, infection with ClYVV produces distortion and mottling in pods without necrosis (22). Depending on the virus strain, environment, cultivar, and vector populations, ClYVV may or may not have a significant effect on harvest yields in processing bean. For example, a severe outbreak of ClYVV was reported recently in a bean field in California, but pods apparently were not affected (3).

Several samples of snap bean plants were received in different years that showed pod necrosis symptoms associated with ClYVV-WI; however, no symptoms were present in leaves and the virus could not be detected in leaf extracts using RTPCR. Infection by movement of infected pollen has been considered as a hypothesis for this occurrence. Among the potyvi- ruses, BCMV, Lettuce mosaic virus, and Pea seedborne mosaic virus have been reported to be pollen transmitted (30) but ClYVV has not. Common bean is selfpollinated and cross-pollination in the field rarely occurs except under high populations of insect pollinators or by wind. Additional studies using ClYVV-WI are required to test this hypothesis. Other pathogens also have been reported to cause necrosis on bean pods. A russet disease on snap bean caused by Plectosporium tabacinum described by Dillard et al. (5) was reported recently that produces symptoms on pods similar to those caused by ClYVV or CMV+AMV. However, no pathogenic fungi were isolated from any of the pods we examined that were infected with ClYVV-WI.

Other than its isolation from snap bean grown in the Great Lakes region, the ultimate source of the ClYVV strain causing chocolate pod is unknown. The strain does appear to be specifically associated with high populations of soybean aphid. Alfalfa (Medicago sativa L.) was considered a potential source of the virus because it is widely grown in regions where snap bean crops are produced and is a known host of ClYVV (22). However, during 2002 and 2003 in New York, Shah et al. (29) investigated potential movement of CMV, AMV, and ClYVV or BYMV into snap bean fields from local and remote alfalfa fields. They found no evidence for an increased risk of virus infection in snap bean adjacent to alfalfa, and no correlation was found between virus incidence in alfalfa and adjacent snap bean.

Unlike other reported common strains of the virus (10-12), ClYVV-WI was undetectable by the Potyvirus broad-spectrumreacting PTY 1 MAb. The inability of PTY 1 to detect ClYVV causing pod necrosis has been problematic with regard to identifying the virus in snap bean each year in the affected regions. PTY 1 has been reported to react to at least 48 different aphid-transmissible potyviruses, including all strains of the BYMV subgroup, including BYMV, Pea mosaic virus, White lupin mosaic virus, and CIYVV $(7,11,12)$. However, in the absence of BYMV, none of the samples collected that were exhibiting the

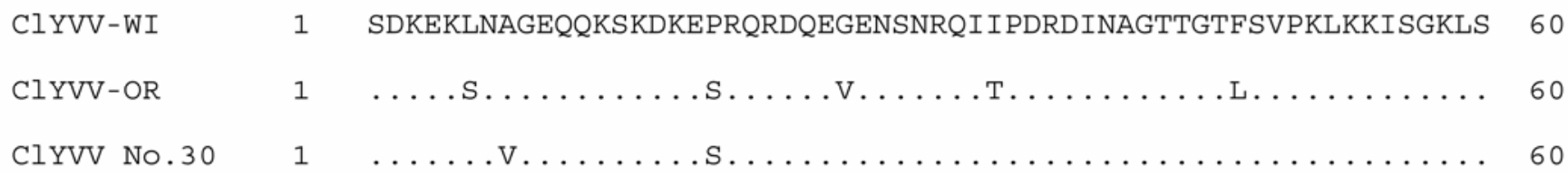

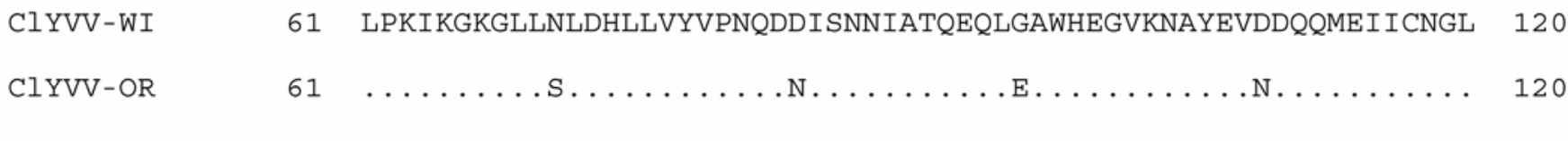

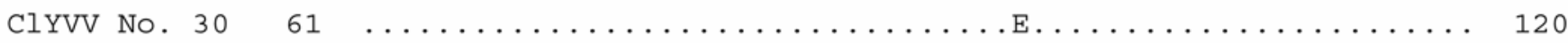

CIYVV-WI 121 MVWCIENGTSGDLQGEWTMMDGEKQVTFPLKPILDFAKPTLRQIMAHFSQAAESYIEFRN 180

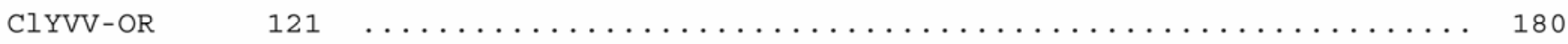

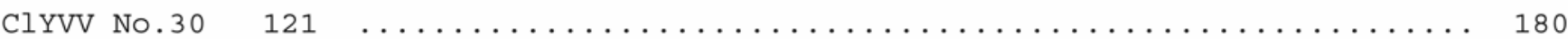

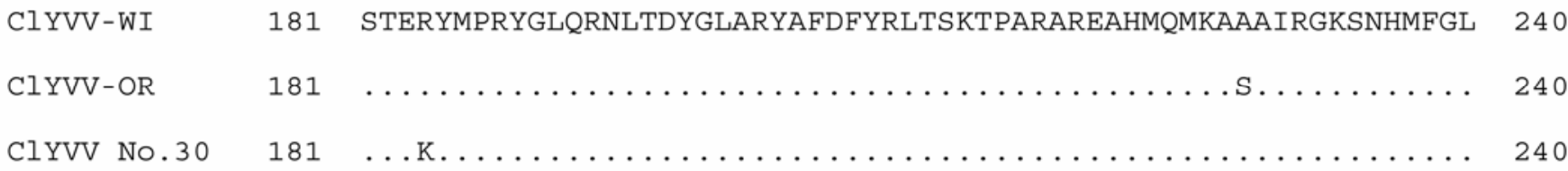

\begin{tabular}{|c|c|c|}
\hline ClYVV-WI & 241 & DGNVGTDEENTERHTANDVNRNMHHIAGARF \\
\hline ClYVV-OR & 241 & 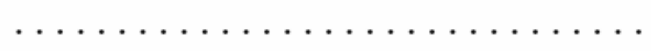 \\
\hline
\end{tabular}

Fig. 3. Amino acid sequence comparison of the coat protein region of Clover yellow vein virus strain from Wisconsin (ClYVV-WI), Oregon (ClYVV-OR), and strain no. 30 (ClYVV No. 30) (26,34) (accession no. NP734172). Amino acids of each strain that differ from those of ClYVV-WI are indicated. 
Table 2. Reaction of commercial snap bean cultivars and breeding lines to inoculation with three strains of Clover yellow vein virus (ClYVV) under greenhouse conditions

\begin{tabular}{|c|c|c|c|}
\hline \multirow[b]{2}{*}{ Cultivar } & \multicolumn{3}{|c|}{ Disease rating ${ }^{\mathrm{a}}$} \\
\hline & WI & OR & NY \\
\hline Angers & 4 & 3 & 4 \\
\hline Arena & 5 & 4 & 5 \\
\hline Banga & 5 & 5 & 5 \\
\hline Benton & 5 & 4 & 4 \\
\hline Booster & 4 & 4 & 3 \\
\hline Bronco & 5 & 4 & 4 \\
\hline Carlo & 4 & 4 & 3 \\
\hline Castano & 5 & 4 & 5 \\
\hline Eden & 5 & 3 & 5 \\
\hline Envy & 5 & 4 & 4 \\
\hline Espada & 5 & 4 & 4 \\
\hline Evergreen & 4 & 3 & 3 \\
\hline Excalibur & 4 & 4 & 4 \\
\hline Firstmate & 5 & 5 & 5 \\
\hline Flo & 5 & 4 & 5 \\
\hline Foremost & 4 & 3 & 3 \\
\hline Gold Crop & 4 & 3 & 4 \\
\hline Goldmine & 5 & 3 & 3 \\
\hline HB 1745 & 4 & 4 & 3 \\
\hline Hercules & 5 & 4 & 5 \\
\hline Hialeah & 4 & 3 & 5 \\
\hline Hystyle & 5 & 4 & 5 \\
\hline IDMV 19 & 5 & 4 & 4 \\
\hline IDMV 20 & 5 & 4 & 4 \\
\hline IDMV 40 & 5 & 3 & 4 \\
\hline Igloo & 5 & 4 & 5 \\
\hline Improved Tendergreen & 5 & 5 & 5 \\
\hline Kentucky Blue & 4 & 4 & 4 \\
\hline Labrador & 5 & 4 & 5 \\
\hline Lynx & 4 & 3 & 3 \\
\hline Masai & 5 & 4 & 5 \\
\hline Medinah & 5 & 3 & 5 \\
\hline Minuette & 4 & 3 & 4 \\
\hline Moncayo & 4 & 3 & 3 \\
\hline MV 185 & 5 & 4 & 5 \\
\hline Nelson & 5 & 4 & 4 \\
\hline Newton & 4 & 4 & 4 \\
\hline Nicelo & 5 & 4 & 4 \\
\hline NY 6020-4 & 5 & 4 & 5 \\
\hline Opera & 5 & 5 & 5 \\
\hline Orion & 4 & 4 & 4 \\
\hline PLS 87 & 3 & 3 & 4 \\
\hline PLS 84 & 5 & 3 & 5 \\
\hline PLS 553 & 5 & 4 & 5 \\
\hline PLS 118 & 5 & 3 & 3 \\
\hline Primo & 5 & 4 & 5 \\
\hline Rambo & 4 & 3 & 4 \\
\hline Roma 442 & 2 & 2 & 2 \\
\hline Romano Gold & 5 & 5 & 5 \\
\hline Sag & 5 & 5 & 5 \\
\hline Saurus & 4 & 3 & 3 \\
\hline SB 4243 & 5 & 4 & 4 \\
\hline Sea Biscuit & 5 & 4 & 4 \\
\hline Serin & 5 & 4 & 4 \\
\hline Sirio & 4 & 4 & 3 \\
\hline Spartacus & 5 & 3 & 5 \\
\hline Summit & 4 & 3 & 5 \\
\hline Tapia & 3 & 3 & 3 \\
\hline Titan & 4 & 3 & 5 \\
\hline Top Crop & 5 & 4 & 5 \\
\hline Ulysess & 4 & 3 & 4 \\
\hline Valentino & 4 & 4 & 4 \\
\hline VR Romano & 5 & 4 & 4 \\
\hline
\end{tabular}

${ }^{a}$ ClYVV strains from Wisconsin (WI), Oregon (OR), and New York (NY). Disease severity index: $1=$ no foliar or pod symptoms; $2=$ mild mosaic, no stunting or apical necrosis; $3=$ mosaic, stunting; $4=$ severe mosaic, severe stunting, leafroll or apical necrosis; and $5=$ vein and apical necrosis followed by death of the plant. chocolate pod disease caused by ClYVVWI and related isolates in 2000-05 from Wisconsin or other states, including Michigan, Minnesota, Ohio, or New York, resulted in positive reactions to this antibody by ELISA (data not shown). Likewise, the Oregon and New York strains used in our evaluations also were not detected. It is not immediately clear why ClYVV-WI or other isolates evaluated from this region did not react with the PTY1 MAb, although similar results have been reported for other Potyvirus isolates. For example, PTY1 did not detect 3 of 15 isolates of Papaya ringspot virus in Florida (1) and Peanut mottle virus isolates $M$ and VS were not detected by Li et al. but another isolate of the virus was detected by the antibody $(11,14)$. A possible reason for lack of detection by PTY 1 may involve weakened avidity due to a difference of one or more of the target amino acids in the core region of the CIYVV-WI CP.

Recent reports have focused on placement of ClYVV isolates into subsets or strains based on serology, host response, and sequence comparisons (25,33). Sasaya et al. (25) described variabilities in 10 isolates of ClYVV collected in Japan that allowed them to be divided into two subsets based on serology, host response, and sequence comparisons. The predicted CP amino acid sequence of ClYVV-WI was $98 \%$ identical with seven isolates in subset 1 and ranged from 91 to $93 \%$ identity with three isolates composing subset 2. ClYVV-WI also produced systemic symptoms of mosaic, severely malformed leaves, and necrosis in $C$. amaranticolor and $C$. quinoa, which was consistent with host responses for the strains reported in subset 1 . Although we were not able to compare serological reactions with the MAbs produced by Sasaya et al. (25), the biological data and molecular sequence comparisons suggest that ClYVV-WI are similar to their isolates in subset 1 . It is unknown if any of the Japanese isolates produced symptoms on snap bean comparable with those caused by ClYVV-WI because pod necrosis was not cited as a symptom (25).

Bean differential hosts UI-31 and US1140 did not develop symptoms in response to inoculation with ClYVV-WI. Provvidenti and Schroeder (23) proposed a single recessive gene, $b y-3$, the symbol of which was later changed to $c y v$ (21), that conferred a high level of resistance to CIYVV in US1140. The gene has been introgressed into some dry bean cultivars (27) but it is not known to be present in any snap bean breeding lines or cultivars. In addition, US1140 possesses $b c-1^{2}$ and UI-31 possesses $b c-1^{2}$ and $b c-2^{2}$, which confer resistance to BCMV. However, the susceptibility of other host differentials with $b c-1^{2}$ or $b c-2^{2}$ resistance genes (Table 1) indicates that resistance to ClYVV, in the case of UI-31 and US1140, is not de- termined by these genes alone that confer resistance to BCMV.

Jolanda and Imuna both possess the desc gene for resistance to ClYVV as well as gene $b c-1$ for resistance to BCMV. The two genes are unrelated because other lines with $b c-1$ were susceptible to ClYVV, as determined by Sato et al (26). Jolanda and Imuna both were susceptible to ClYVVWI, but exhibited symptoms less severe than their BCMV host group counterparts in this study. The susceptibility of lines with reported resistance to ClYVV (28) provides additional evidence that ClYVVWI may be a unique strain of virus.

Except for IVT 7214, genotypes with the $b c-3$ gene for resistance to BCMV and BCMNV were resistant to ClYVV-WI. These results suggest that $b c-3$, or a gene tightly linked with $b c-3$, may be associated with resistance to CIYVV-WI.

Because ClYVV is transmitted by aphids in a nonpersistent manner, the use of pesticides to manage the spread of the virus is generally ineffective. Hence, the most effective management strategy is to develop cultivars with resistance or tolerance to ClYVV. Unfortunately, no snap bean cultivars currently in production exhibit resistance to the virus. It is likely that Roma 442 may be grown successfully in areas with a high incidence of ClYVV, although evaluation under field conditions is a prerequisite for this recommendation. In addition, because it is a flat-pod processing Romano type, production is limited compared with the more popular roundpodded snap bean types. Introgression of the $b c-3$ gene into current snap bean cultivars may offer resistance against ClYVV, but further investigation is warranted to verify that $b c-3$ confers resistance to ClYVV.

\section{ACKNOWLEDGMENTS}

ClYVV-NY was kindly supplied by A. Taylor, Cornell University.

\section{LITERATURE CITED}

1. Baker, C. A., Lecoq, H., and Purcifull, D. E. 1991. Serological and biological variability among Papaya ringspot virus type-W isolates in Florida. Phytopathology. 81:722-728.

2. Converse, R., and Martin, R. 1990. Pages 179196 in: Serological Methods for Detection and Identification of Viral and Bacterial Plant Pathogens. R. Hampton, E. Ball, and S. De Boer, eds. American Phytopathological Society, St. Paul, MN.

3. Crnov, R. and Gilbertson, R. L. 2001. Outbreak of Clover yellow vein virus in a bean field in Colusa County, California. Plant Dis. 85:444.

4. Dellaporta, S. L. 1993. Plant DNA miniprep and microprep: version 2.1-2.3. Pages 522-525 in: The Maize Handbook. M. Freeling and V. Walbot, eds. Springer-Verlag, New York.

5. Dillard H. R., Cobb A. C., Shah D. A., and Straight K. E. 2005. Identification and characterization of russet on snap beans caused by Plectosporium tabacinum. Plant Dis. 89:700704.

6. Drifjhout, E., Silbernagel, M. J., and Burke, D. W. 1978. Differentiation of strains of Bean common mosaic virus. Neth. J. P1ant 
Pathol. 84:13-26.

7. Guaragna, M. A., Jordan, R. L., and Putnam, M. L. 2004. First report of Bean yellow mosaic virus (pea mosaic strain) in Verbena $\times$ hybrida. Plant Dis. 88:574.

8. Grau, C. R., Stevenson, W. R., and Mondjana, A. M. 2002. Viruses causing losses on processing beans in the Midwest. Proc. Wis. Fertilizer, Aglime, Pest Manage. Conf. 41:248-256.

9. Hill, J. H., Alleman, R., Hogg, D. B., and Grau, C.R. 2001. First report of transmission of Soybean mosaic virus and Alfalfa mosaic virus by Aphis glycines in the New World. Plant Dis. 85:561.

10. Jordan, R. 1989. Mapping of potyvirusspecific and group-common antigenic determinants with monoclonal antibodies by westernblot analysis and coat protein amino acid sequence comparisons. (Abstr.) Phytopathology 79:1157.

11. Jordan, R. 1992. Potyviruses, monoclonal antibodies, and antigenic sites. Arch. Virol. (Suppl. 5):81-95.

12. Jordan, R., and Hammond, J. 1991. Comparison and differentiation of potyvirus isolates and identification of strain-, virus-, subgroupspecific and potyvirus group-common epitopes using monoclonal antibodies. J. Gen. Virol. 72:25-36.

13. Larsen, R. C., Miklas, P. N., Eastwell, K. C., Grau, C. R., and Mondjana, A. 2002. A virus disease complex devastating late season snap bean production in the Midwest. Bean Improv. Coop. Proc. 45:36-37.

14. Li, R. H., Zettler, F. W., Elliott, M. S., Petersen, M. A., Still, P. E., Baker, C. A., and Mink, G. I. 1991. A strain of Peanut mottle virus seedborne in bambarra groundnut. Plant Dis. 75:130-133.

15. Miklas, P. N., and Hang, A. N. 1998. Release of cranberry dry bean germplasm lines USCR7 and USCR-8 with resistance to Bean common mosaic and necrosis viruses. Annu. Rep. Bean Improv. Coop. 41:227-228.

16. Miklas, P. N., and Hang, A. N. 1998. Release of dark red and white kidney dry bean germ- plasm lines USDK-4, USDK-5, and USWK-6 with resistance to Bean common mosaic and necrosis viruses. Annu. Rep. Bean Improv. Coop. 41:229-230.

17. Miklas, P. N, and Hang, A. N. 1998. Release of light red kidney dry bean germplasm lines USLK-1, -2, and -3 with resistance to Bean common mosaic and necrosis viruses. Annu. Rep. Bean Improv. Coop. 41:231-232.

18. Miklas, P. N., Hang, A. N., Kelly, J. D., Strausbaugh, C. A., and Forster, R. L. 2002. Registration of three kidney bean germplasm lines resistant to Bean common mosaic and necrosis potyviruses: USLK-2 light red kidney, USDK-4 dark red kidney, and USWK-6 white kidney. Crop Sci. 42:674-675.

19. Miklas, P. N., and Kelley, J. D. 2002. Registration of two cranberry bean germplasm lines resistant to Bean common mosaic and necrosis potyviruses: USCR-7 and USCR-9. Crop Sci. 42:673-674.

20. Presting, G. G., Smith, O. P., and Brown, C. R. 1995. Resistance to potato leafroll virus in potato plants transformed with the coat protein gene or with vector control constructs. Phytopathology 85:436-442.

21. Provvidenti, R. 1987. List of genes in Phaseolus vulgaris for resistance to viruses. Annu. Rep. Bean Improv. Coop. 30:1-4.

22. Provvidenti, R., and Morales, F. J. 2005. Clover yellow vein virus. Pages 75-76 in: Compendium of Bean Diseases. H. F. Schwartz, ed. American Phytopathological Society, St. Paul, MN.

23. Provvidenti, R., and Schroeder, W. T. 1973. Resistance in Phaseolus vulgaris to the severe strain of Bean yellow mosaic virus. Phytopathology 63:196-197.

24. Sambrook, J., Fritsch, E. F., and Maniatis, T. 1989. Molecular Cloning: A Laboratory Manual, 2nd ed. Cold Spring Harbor Laboratory Press, Cold Spring Harbor, NY.

25. Sasaya, T., Shimizu, T., Nozu, Y., Nishiguchi, M., Inouye, N., and Koganezawa, H. 1997. Biological, serological, and molecular variabilities of Clover yellow vein virus. Phytopa- thology 87:1014-1019.

26. Sato, M., Masuta, C., and Uyeda, I. 2003 Natural resistance to Clover yellow vein virus in beans controlled by a single recessive locus. Mol. Plant-Microbe Interact. 16:994-1002.

27. Scully, B., Provvidenti, R., Benscher, D., Halseth, D. E., Miller, J. C., and Wallace, D. H. 1995. Five multiple-virus-resistant common bean breeding lines. HortScience 30:13201323.

28. Scully, B., Provvidenti, R., Halseth, D. E., and Wallace, D. H. 1991. CU-M90: a black dry bean breeding line resistant to Clover yellow vein virus. HortScience 26:435-436.

29. Shah, D. A., Dillard, H. R., MazumdarLeighton, S., Gonsalves, D., and Nault, B. A 2006. Incidence, spatial patterns, and associations among viruses in snap bean and alfalfa in New York. Plant Dis. 90:203-210.

30. Shukla, D. D., Ward, C. W., and Brunt, A. A. 2004. The Potyviridae. CAB International, Wallingford, UK

31. Stevenson, W. R., Grau, C. R and German, T. L. 2006. Reaction of snap bean cultivars and advanced breeding lines to aphid transmitted viruses. Proc. Wis. Fertilizer, Aglime, Pest Manage. Conf. 45:249-256.

32. Tachel, S. P., Baggett, J. R., and Hampton, R. O. 1985. Relationship between resistance to severe and type strains of Bean yellow mosaic virus. J. Am. Soc. Hortic. Sci. 110:9699.

33. Uga, H., Kobayashi, Y. O., Hagiwara, K., Honda, Y., Omura, T., and Sasaya, T. 2002. Molecular characterization of Bean yellow mosaic virus from vegetatively propagated dwarf Gentiana plants. J. Gen Plant Pathol. 68:378 381.

34. Uyeda, I., Takahashi, T., and Shikata, E. 1991. Relatedness of the nucleotide sequence of the 3 -terminal region of Clover yellow vein potyvirus RNA to Bean yellow mosaic potyvirus RNA. Intervirology 32:234-45.

35. USDA National Agricultural Statistics Service. 2005. Online publication. United States Department of Agriculture, Washington DC. 